Article

\title{
Synthesis of Mesoporous CuO Hollow Sphere Nanozyme for Paper-Based Hydrogen Peroxide Sensor
}

\author{
Dong Cheng, Jing Qin, Youyou Feng and Jing Wei * \\ The Key Laboratory of Biomedical Information Engineering of Ministry of Education, Institute of Analytical \\ Chemistry and Instrument for Life Science, School of Life Science and Technology, Xi'an Jiaotong University, \\ Xi'an 710049, China; cd20190911@stu.xjtu.edu.cn (D.C.); soyoung@stu.xjtu.edu.cn (J.Q.); \\ qq512182235@stu.xjtu.edu.cn (Y.F.) \\ * Correspondence: jingwei@xjtu.edu.cn
}

\section{check for} updates

Citation: Cheng, D.; Qin, J.; Feng, Y.; Wei, J. Synthesis of Mesoporous CuO Hollow Sphere Nanozyme for Paper-Based Hydrogen Peroxide Sensor. Biosensors 2021, 11, 258. https://doi.org/10.3390/bios11080258

Received: 29 June 2021

Accepted: 28 July 2021

Published: 30 July 2021

Publisher's Note: MDPI stays neutral with regard to jurisdictional claims in published maps and institutional affiliations.

Copyright: (c) 2021 by the authors. Licensee MDPI, Basel, Switzerland. This article is an open access article distributed under the terms and conditions of the Creative Commons Attribution (CC BY) license (https:// creativecommons.org/licenses/by/ $4.0 /)$.

\begin{abstract}
Point-of-care monitoring of hydrogen peroxide is important due to its wide usage in biomedicine, the household and industry. Herein, a paper sensor is developed for sensitive, visual and selective detection of $\mathrm{H}_{2} \mathrm{O}_{2}$ using a mesoporous metal oxide hollow sphere as a nanozyme. The mesoporous $\mathrm{CuO}$ hollow sphere is synthesized by direct decomposition of copper-polyphenol colloidal spheres. The obtained mesoporous $\mathrm{CuO}$ hollow sphere shows a large specific surface area $\left(58.77 \mathrm{~m}^{2} / \mathrm{g}\right)$, pore volume $\left(0.56 \mathrm{~cm}^{3} / \mathrm{g}\right)$, accessible mesopores $(5.8 \mathrm{~nm})$, a hollow structure and a uniform diameter $(100 \mathrm{~nm})$. Furthermore, they are proven to show excellent peroxidaselike activities with $K_{\mathrm{m}}$ and $V_{\max }$ values of $120 \mathrm{mM}$ and $1.396 \times 10^{-5} \mathrm{M} \cdot \mathrm{s}^{-1}$, respectively. Such mesoporous $\mathrm{CuO}$ hollow spheres are then loaded on the low-cost and disposable filter paper test strip. The obtained paper sensor can be effectively used for detection of $\mathrm{H}_{2} \mathrm{O}_{2}$ in the range of 2.4-150 $\mu \mathrm{M}$. This work provides a new kind of paper sensor fabricated from a mesoporous metal oxide hollow sphere nanozyme. These sensors could be potentially used in bioanalysis, food security and environmental protection.
\end{abstract}

Keywords: polyphenol; mesoporous metal oxide; hollow sphere; nanozyme; paper sensor

\section{Introduction}

Hydrogen peroxide $\left(\mathrm{H}_{2} \mathrm{O}_{2}\right)$ is a strong oxidant and bleaching agent. It has been widely applied in biomedicine, the household and industry. $\mathrm{H}_{2} \mathrm{O}_{2}$ is also a reactive oxygen species (ROS), which play essential roles in many physiological and pathological processes [1-4]. Furthermore, $\mathrm{H}_{2} \mathrm{O}_{2}$ is linked to many human diseases, including cardiovascular disorders, diabetes, Parkinson's disease, Alzheimer's disease, Huntington's disease, metabolic diseases and cancers $[5,6]$. Therefore, detection of $\mathrm{H}_{2} \mathrm{O}_{2}$ is very important for both academic and industrial purposes. The development of low-cost, simple, fast, sensitive and selective $\mathrm{H}_{2} \mathrm{O}_{2}$ sensors is imperative. At present, various sensors have been developed to detect hydrogen peroxide [7]. Generally, the detection methods mainly include electrochemical methods [8,9], chromatography [10], fluorescence [11,12], chemiluminescence [13,14], colorimetry [15-17] etc. However, most of the methods require the use of expensive and bulky instruments and equipment. As a result, there is an urgent need to develop simple, low-cost detection methods that do not require bulky instruments.

Paper sensors have been widely used in point-of-care detection due to their simplicity, low cost, visual detection, portability and minimal sample consumption [18-20]. It can be useful for qualitative and quantitative analyses with a range of analysis. At present, many paper-based sensing platforms have been developed using nanomaterials to enhance the detecting signals [21]. These nanomaterials showed efficient enzyme-like activity [18,22,23]. For example, Zhang et al. fabricated a paper sensor with mesoporous carbon loaded with $\mathrm{Pd}$ nanoparticles as a highly active peroxidase mimic for $\mathrm{H}_{2} \mathrm{O}_{2}$ detection [24]. Since the discovery of the $\mathrm{Fe}_{3} \mathrm{O}_{4}$ nanozyme in 2007 [25], metal oxide nanomaterials have been widely 
studied as efficient enzyme mimics. At present, $\mathrm{CeO}_{2}$ [26], $\mathrm{NiO}$ [27], $\mathrm{MnO}_{2}$ [28], $\mathrm{V}_{2} \mathrm{O}_{5}$ [29] and $\mathrm{CuO}[30]$, and others [31,32], have been found to show enzyme-like activities, such as peroxidase, catalase, oxidase and other activities. Ceria oxide and iron oxide are the most widely studied nanozymes [26,33]. Comparably, copper oxide is relatively less studied. $\mathrm{CuO}$, a transition metal oxide with a narrow bandgap $(\sim 2.0 \mathrm{eV})$, has many excellent properties, such as low cost, easy mixing with polymers and relative stability in terms of both chemical and physical properties, high surface-to-volume ratio and easy preparation [34,35]. Therefore, $\mathrm{CuO}$ nanomaterials of various structures have been synthesized [36-39] and used for antibacterial, antioxidant and sensing purposes [40-42].

Mesoporous metal oxide hollow spheres exhibit a tunable pore size $(2-50 \mathrm{~nm})$, a large specific surface area, tailorable compositions, highly accessible pore channels and shortening mass transfer pathways. They have attracted broad applications in catalysis, sensors, energy conversion and storage $[43,44]$. When mesoporous metal oxide hollow spheres are used for nanozyme and paper-based sensors, they demonstrate several advantages. Firstly, mesoporous metal oxide hollow sphere nanozymes have a large specific surface area and a large number of accessible active sites $[45,46]$. Such active sites would facilitate the catalytic reaction on the surface of nanozyme and increase the sensitivity. Secondly, mesoporous metal oxide hollow sphere nanozymes show interconnected mesoporous channels, large pore sizes and a uniform diameter, which can favor mass transfer and thus enable fast detection $[47,48]$. Thirdly, mesoporous metal oxide hollow sphere nanozymes have large internal voids that can load other guests, such as enzymes, metal nanoparticles and reporter molecules $[49,50]$. Due to the flexibility of mesoporous structure and compositions, mesoporous metal oxide hollow sphere nanozymes have many applications in biosensors, antibacterial drug delivery and therapy. Until now, there has been no report on the synthesis of mesoporous $\mathrm{CuO}$ hollow sphere nanozymes for paper-based $\mathrm{H}_{2} \mathrm{O}_{2}$ sensors.

Herein, mesoporous $\mathrm{CuO}$ hollow sphere nanozymes are prepared for paper-based $\mathrm{H}_{2} \mathrm{O}_{2}$ sensors (Scheme 1). A sol-gel synthesis strategy is used to prepare copper-polyphenol coordination colloidal spheres using plant polyphenol (i.e., tannic acid, (TA)) as a polymerizable ligand, formaldehyde as a crosslinker and cupric ions as a metal source. After further thermal decomposition, mesoporous $\mathrm{CuO}$ hollow spheres are obtained. The obtained mesoporous $\mathrm{CuO}$ hollow spheres show a large specific surface area, large mesopore size, uniform particle size and excellent peroxidase activity. Such nanozymes are then used to fabricate low-cost, easy-to-use, portable and disposable paper sensors for the detection of $\mathrm{H}_{2} \mathrm{O}_{2}$.

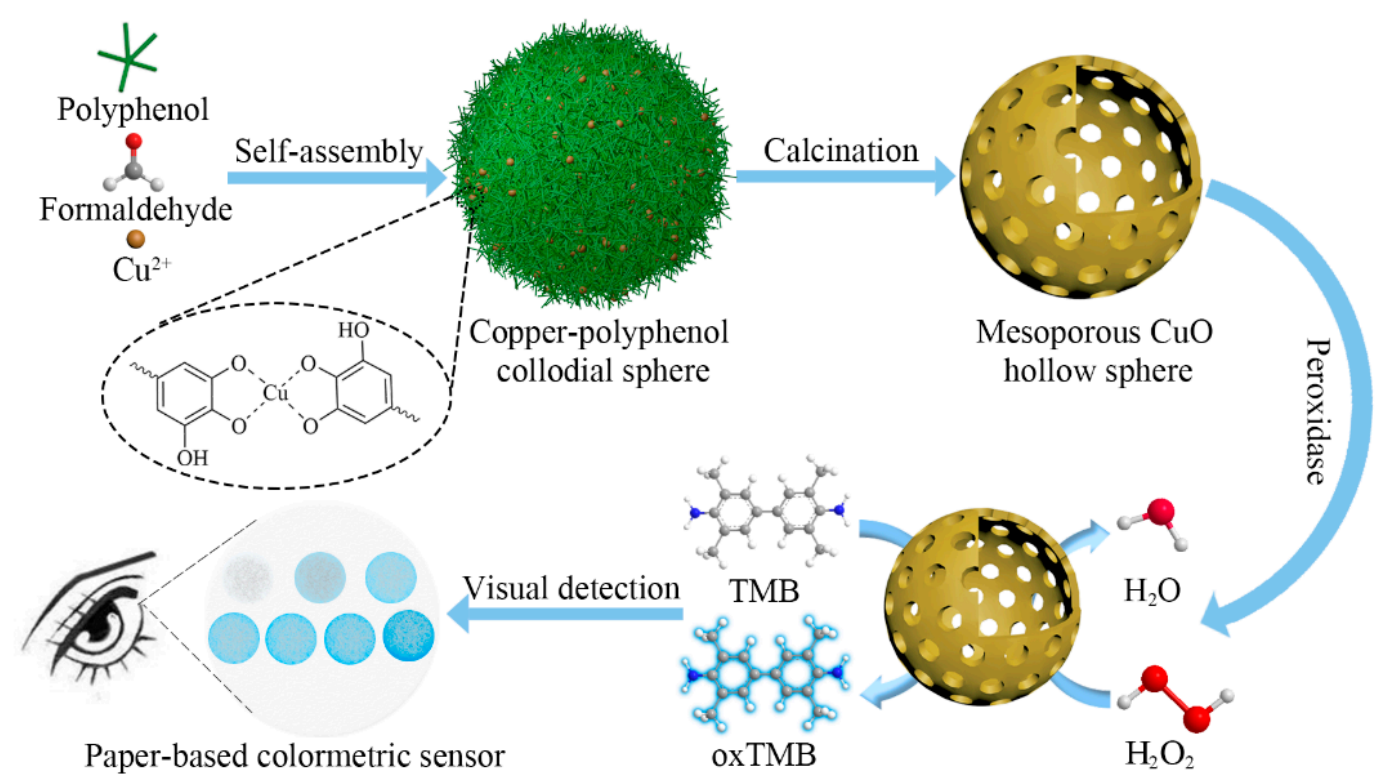

Scheme 1. Schematic illustration of the synthesis of mesoporous $\mathrm{CuO}$ hollow sphere nanozymes and their application as a paper-based sensor for colorimetric detection of $\mathrm{H}_{2} \mathrm{O}_{2}$. 


\section{Materials and Methods}

\subsection{Materials}

Tannic acid (TA), $\mathrm{Cu}\left(\mathrm{NO}_{3}\right)_{2} \cdot 3 \mathrm{H}_{2} \mathrm{O}$, ethanol, hydrogen peroxide (30 wt\%), 3,3',5,5'-tetramethylbenzidine (TMB), L-proline, glycine, cysteine, alanine, glutamic acid, $\mathrm{NaCl}, \mathrm{KCl}, \mathrm{MnCl}_{2} \cdot 4 \mathrm{H}_{2} \mathrm{O}, \mathrm{CaCl}_{2}$, glucose and L-glutathione reduced were purchased from Macklin Biochemical Co., Ltd. Ammonia solution (25-28 wt\%) and formaldehyde (37-40 wt\%) were purchased from Tianjin Zhiyuan Chemical Co., Ltd. Pluronic ${ }^{\circledR}$ F127 was purchased from Sigma-Aldrich. The qualitative filter paper was purchased from Whatman. All the reagents were used without further purification. Deionized water from a Milli-Q Plus system (Millipore) was used in all experiments.

\subsection{Synthesis of Mesoporous CuO Hollow Sphere}

The mesoporous $\mathrm{CuO}$ hollow sphere was synthesized by direct decomposition of metal-polyphenol colloidal spheres. Metal-polyphenol colloidal spheres were synthesized according to our previous reports with minor modifications [51,52]. The detailed synthesis procedure is shown in the Supplementary Materials. Mesoporous $\mathrm{CuO}$ hollow spheres were obtained by calcination of metal-polyphenol colloidal spheres at $350{ }^{\circ} \mathrm{C}$ for $2 \mathrm{~h}$ in the air with a ramping rate of $2 \% \mathrm{~min}$. The metal-polyphenol colloidal spheres and their derived mesoporous $\mathrm{CuO}$ hollow spheres were denoted as $\mathrm{Cu}-\mathrm{TA}$ and $\mathrm{Cu}-\mathrm{TA}-350$, respectively.

\subsection{Mimic Peroxidase Activity of Mesoporous CuO Hollow Sphere}

The mimic peroxidase properties of $\mathrm{Cu}$-TA-350 were tested by dispersing $20 \mu \mathrm{L}$ of $\mathrm{Cu}-\mathrm{TA}-350(1 \mathrm{mg} / \mathrm{mL})$ in water solutions in the presence of $150 \mu \mathrm{L}$ of PBS buffer $(\mathrm{pH}=5.0)$ and $80 \mu \mathrm{L}$ of TMB $(10 \mathrm{mM})$ and $\mathrm{H}_{2} \mathrm{O}_{2}(10-600 \mathrm{mM})$ with a total volume of $1.0 \mathrm{~mL}$. After the mixed solution was processed at room temperature for $5 \mathrm{~min}$, the photographs and UV spectra of the mixtures were taken. The kinetic analysis of the peroxidase-like activity of Cu-TA-350 was investigated by monitoring absorbance after changing the concentration of $\mathrm{H}_{2} \mathrm{O}_{2}$. To analyze the reaction kinetic, the absorbance variation of the reaction solution was recorded in time scan mode at $652 \mathrm{~nm}$. The kinetic parameters of the catalytic reaction were calculated based on the Michaelis-Menten function $v=V_{\max }[\mathrm{S}] /\left(K_{m}+[\mathrm{S}]\right)$, where $v$ is the initial velocity, $V_{\max }$ represents the maximal reaction velocity, [S] corresponds to the concentration of substrate, and $K_{m}$ is the Michaelis constant.

\section{4. $\mathrm{H}_{2} \mathrm{O}_{2}$ Detection Using Mesoporous $\mathrm{CuO}$ Hollow Sphere}

For $\mathrm{H}_{2} \mathrm{O}_{2}$ detection, $\mathrm{Cu}$-TA-350 $(20 \mu \mathrm{L}, 1 \mathrm{mg} / \mathrm{mL})$ was added into aqueous solution containing $150 \mu \mathrm{L}$ of PBS buffer $(0.5 \mathrm{mM}, \mathrm{pH}=5.0), 80 \mu \mathrm{L}$ of TMB $(10 \mathrm{mM})$. After $5 \mathrm{~min}$, $\mathrm{H}_{2} \mathrm{O}_{2}$ was added to the solution. The final concentration of $\mathrm{H}_{2} \mathrm{O}_{2}$ ranges was from 10 to $600 \mu \mathrm{M}$. After another $5 \mathrm{~min}$, the absorbance was recorded with a UV-Vis spectrophotometer. The corresponding color changes of the reaction solution were photographed by a smartphone. To verify the selectivity of the Cu-TA-350 based colorimetry, common cations $\left(\mathrm{K}^{+}, \mathrm{Na}^{+}, \mathrm{Ca}^{2+}, \mathrm{Mg}^{2+}\right.$ and $\mathrm{Mn}^{2+}$ ) and other substrates (ascorbic acid (AA), glucose (Glc), proline (Pro), glycine (Gly), glutamate (Glu) and alanine (Ala)) were similarly tested.

\subsection{Fabrication of Paper-Based Sensor}

For the fabrication of a paper-based sensor, filter paper with a pore size of $8 \mu \mathrm{M}$ was immersed in Cu-TA-350 (1 mg/mL) solution for 5 min followed by drying in air. Then the filter paper was cut into pieces of $1 \mathrm{~cm} \times 1 \mathrm{~cm}$ and stored at room temperature. For the detection of $\mathrm{H}_{2} \mathrm{O}_{2}, 5 \mu \mathrm{L}$ of TMB $(10 \mathrm{mM})$ solution was dropped onto the paper piece and dried at room temperature for $30 \mathrm{~s}$. Subsequently, $5 \mu \mathrm{L}$ of samples with different concentrations of $\mathrm{H}_{2} \mathrm{O}_{2}$ were dropped on each corresponding paper piece. $\mathrm{H}_{2} \mathrm{O}_{2}$ was the substate of this catalytic reaction. Cu-TA-350 was used to oxidize the colorless substrate TMB into a blue product. After reacting for $5 \mathrm{~min}$, the samples were rapidly photographed using a smartphone (iPhone 12). The camera was located at a constant height of $10 \mathrm{~cm}$ above the paper. Every test was under the same indoor conditions. The photograph of the 
paper was analyzed for the RGB value. The average of these individual color readings was calculated for each strip and was plotted as a function of different concentrations of $\mathrm{H}_{2} \mathrm{O}_{2}$ $(10-150 \mu \mathrm{M})$. The selectivity of the sensor was evaluated by dropping different common cations $\left(\mathrm{K}^{+}, \mathrm{Na}^{+}, \mathrm{Ca}^{2+}, \mathrm{Mg}^{2+}\right.$ and $\left.\mathrm{Mn}^{2+}\right)$ and other substrates, including ascorbic acid (AA), cysteine (Cys), glucose (Glc), proline (Pro), glycine (Gly), glutamate (Glu) and alanine (Ala), on the paper-based sensor. The concentrations of metal ions and glucose were $1 \mathrm{mM}$, while the concentrations of AA, GSH and amino acids were $100 \mu \mathrm{M}$. The repeatability of the paper-based sensor was evaluated by measuring the color of 9 batches of the paper-based sensor. The paper-based sensor was stored in sealed bags at $25^{\circ} \mathrm{C}$. The storage stability was assessed by measuring the color intensity of identical paper-based sensor in response to $\mathrm{H}_{2} \mathrm{O}_{2}(100 \mu \mathrm{M})$ at various time intervals.

\section{Results}

\subsection{Synthesis and Characterization of Mesoporous $\mathrm{CuO}$ Hollow Spheres}

Mesoporous $\mathrm{CuO}$ hollow spheres were synthesized via a modified sol-gel process (Scheme 1). Firstly, copper-polyphenol colloidal spheres were synthesized via a formaldehydeassisted metal-ligand crosslinking strategy using tannic acid as a polymerizable ligand, cupric ions as a metal source and formaldehyde as a crosslinker in the alkaline condition. Secondly, mesoporous $\mathrm{CuO}$ hollow spheres were obtained using the copper-polyphenol colloidal spheres as a precursor via a direct thermal decomposition process. During the calcination process, the organic framework was decomposed into gaseous $\mathrm{CO}_{2}$ and $\mathrm{H}_{2} \mathrm{O}$, which can induce the formation of the mesoporous framework. The inhomogeneous shrinkage during this calcination process induced the formation of the hollow structure. The metal-polyphenol colloidal spheres and their derived mesoporous $\mathrm{CuO}$ hollow sphere were denoted $\mathrm{Cu}-\mathrm{TA}$ and $\mathrm{Cu}-\mathrm{TA}-350$, respectively.

SEM image for $\mathrm{Cu}$-TA revealed spherical morphology (Figure 1a). The average diameter was approximately $200 \mathrm{~nm}$. After calcination, the obtained Cu-TA-350 had retained spherical structure (Figure $1 \mathrm{~b}$ ). The average diameter of $\mathrm{Cu}-\mathrm{TA}-350$ was around $100 \mathrm{~nm}$. The sharp decrease in particle size was due to severe shrinkage during the thermal decomposition process. It should be noted that the sphere showed an obvious mesoporous framework. Transmission electron microscopy (TEM) images of Cu-TA-350 further confirmed the spherical structure with large voids (Figure 1c). The high-resolution TEM image of Cu-TA-350 showed a crystalline structure with a d-spacing of 0.23 and $0.25 \mathrm{~nm}$, which could be assigned to the (111) and (002) planes of mesoporous $\mathrm{CuO}$, respectively (Figure 1d). The selected area electron diffraction (SAED) pattern of Cu-TA-350 revealed a polycrystalline feature (Figure S1a). Furthermore, nitrogen sorption isotherms (Figure 1e) showed that $\mathrm{Cu}-\mathrm{TA}-350$ exhibited a typical IV-type desorption curve, indicating a mesoporous structure. The specific surface area and pore volume were $58.7 \mathrm{~m}^{2} / \mathrm{g}$ and $0.56 \mathrm{~cm}^{3} / \mathrm{g}$, respectively. The pore size was $5.8 \mathrm{~nm}$ (Figure 1f).

$\mathrm{X}$-ray diffraction (XRD) patterns of the Cu-TA-350 displayed distinct diffraction peaks, indicating a highly crystalline framework (Figure $1 \mathrm{~g}$ ). The diffraction peaks at $2 \theta$ values of $32.52^{\circ}, 35.56^{\circ}, 38.72^{\circ}, 46.29^{\circ}, 48.79^{\circ}, 51.36^{\circ}, 53.48^{\circ}, 58.30^{\circ}, 61.58^{\circ}, 65.81^{\circ}, 66.30^{\circ}, 68.12^{\circ}$ and $75.29^{\circ}$ could be indexed to (110), (002), (111), (-112), (-202), (112), (020), (202), (-113), (022), (-311), (220), (311) and (-222) planes of crystalline CuO (JCPDS no.89-5896). Furthermore, XRD patterns also showed two weak diffraction peaks at $2 \theta$ values of $36.42^{\circ}$ and $42.30^{\circ}$. They could be indexed to (111) and (200) planes of crystalline $\mathrm{Cu}_{2} \mathrm{O}$ (JCPDS no.77-0199). There is a small amount of $\mathrm{Cu}_{2} \mathrm{O}$ mixed in the $\mathrm{CuO}$, which may be caused by the fact that part of the $\mathrm{Cu}$ is not safely oxidized during the calcination process [53]. X-ray photoelectron spectroscopy was used to study the surface properties and oxidation states of the $\mathrm{Cu}$ in the $\mathrm{Cu}$-TA-350 (Figure $1 \mathrm{~h}$ ). The $\mathrm{Cu} 2 \mathrm{p}$ spectrum showed two peaks at binding energies (BEs) of 933 and $953.1 \mathrm{eV}$, which were ascribed to the $\mathrm{Cu} 2 \mathrm{p}_{3 / 2}$ and $\mathrm{Cu} 2 \mathrm{p}_{1 / 2}$ lines, respectively. The $\mathrm{Cu} 2 \mathrm{p}_{3 / 2}$ peak could be fitted to two peaks with BEs of 934.0 and $932.7 \mathrm{eV}$, corresponding to $\mathrm{Cu}(\mathrm{I})$ and $\mathrm{Cu}(\mathrm{II})$, respectively. Moreover, shakeup satellites were at 940.6 
and $943.1 \mathrm{eV}$. These results demonstrated that the mesoporous $\mathrm{CuO}$ hollow sphere was successfully synthesized.

a

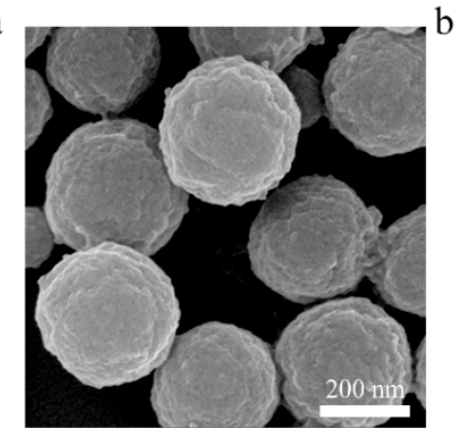

d

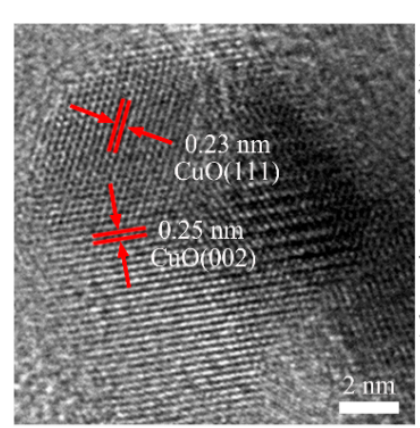

g

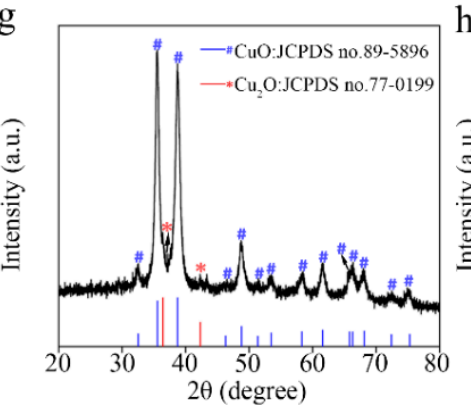

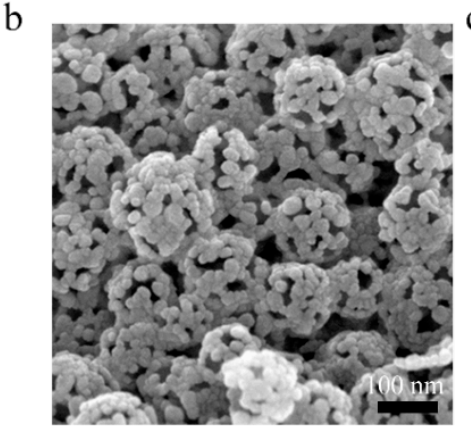

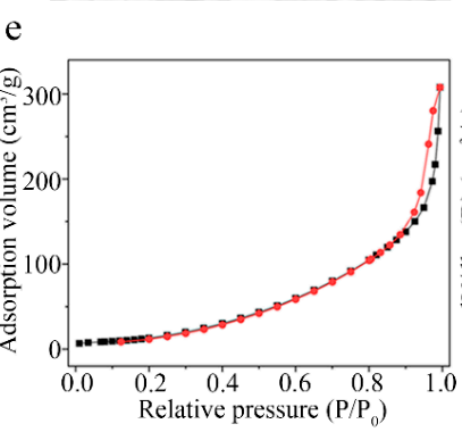

$\mathrm{h}$

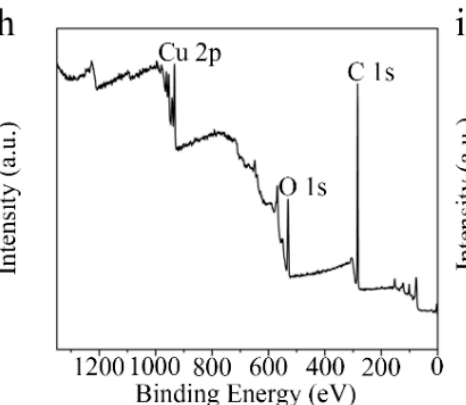

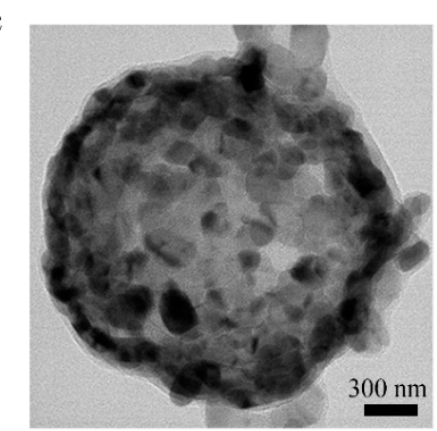

$\mathrm{f}$
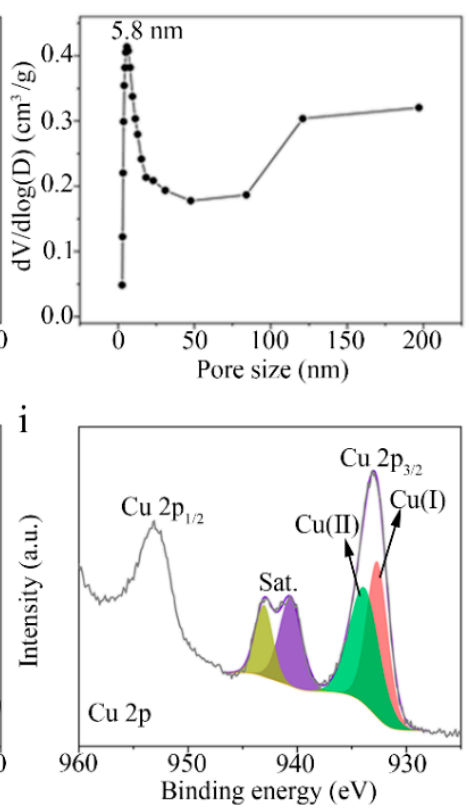

Figure 1. SEM images of (a) Cu-TA and (b) Cu-TA-350. (c) TEM and (d) high-resolution TEM images for Cu-TA-350. (e) $\mathrm{N}_{2}$ sorption isotherms and (f) corresponding pore size distributions for Cu-TA-350. (g) XRD patterns, (h) XPS survey spectra and (i) $\mathrm{Cu} 2 \mathrm{p}$ spectra for Cu-TA-350.

\subsection{Peroxidase-Like Activity}

To investigate the peroxidase-like activity of mesoporous $\mathrm{CuO}$ hollow spheres, a typical reaction of the catalytic oxidation of 3,3',5,5'-tetramethylbenzidine (TMB) in the presence of $\mathrm{H}_{2} \mathrm{O}_{2}$ was adopted. As depicted in Figure 2a, Cu-TA-350 can catalyze the oxidation of TMB to form oxidized TMB (oxTMB). Mesoporous $\mathrm{CuO}$ hollow spheres can break the $\mathrm{O}-\mathrm{O}$ bond of $\mathrm{H}_{2} \mathrm{O}_{2}$, producing two $\mathrm{OH}$, while TMB can be oxidized by $\cdot \mathrm{OH}$ to form oxTMB. The colorless mixture of TMB and $\mathrm{H}_{2} \mathrm{O}_{2}$ changed to a blue solution after adding $\mathrm{Cu}$-TA-350. In contrast, negligible absorbance was observed in the presence of TMB and $\mathrm{H}_{2} \mathrm{O}_{2}$ (Figure $2 \mathrm{~b}$ ). It could be observed that $\mathrm{Cu}$-TA-350 has enzymatic activity, while $\mathrm{Cu}^{2+}$ plays a role in enzymatic catalysis (Figure S2). These results successfully identified the peroxidase-like activity of $\mathrm{Cu}-\mathrm{TA}-350$ rather than the leached $\mathrm{Cu}^{2+}$. Meanwhile, the absorbance of the system at $652 \mathrm{~nm}$ noticeably increased as the reaction proceeded over 5 min (Figure S3a). The absorbance value increased gradually when more $\mathrm{Cu}$-TA-350 was used. Therefore, Cu-TA-350 dispersed solution was selected for the following experiments. In addition, similar to the natural enzyme, the effects of the concentration of TMB, $\mathrm{pH}$ value and temperature on peroxidase-like activity of Cu-TA-350 were investigated. The absorbance gradually increased when the concentrations of TMB increased (Figure S3b). 
The peroxidase activity of $\mathrm{Cu}-\mathrm{TA}-350$ was best achieved at a $\mathrm{pH}$ value of 5.0 (Figure $\mathrm{S3c}$ ) or at a temperature of $40{ }^{\circ} \mathrm{C}$ (Figure S3d). In the buffer solution with a $\mathrm{pH}$ of 5, Cu-TA-350 may show enhanced interaction with TMB molecules, promoting the catalytic oxidation of TMB with $\mathrm{H}_{2} \mathrm{O}_{2}$ [54].

a

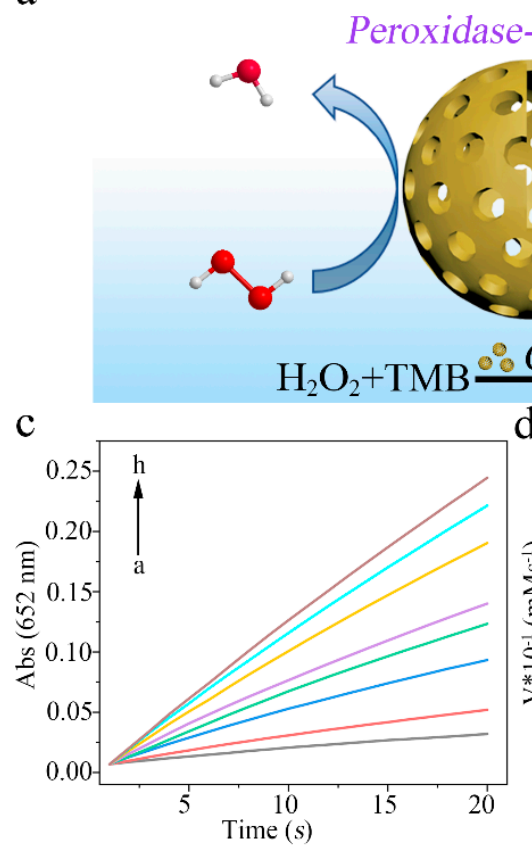

b

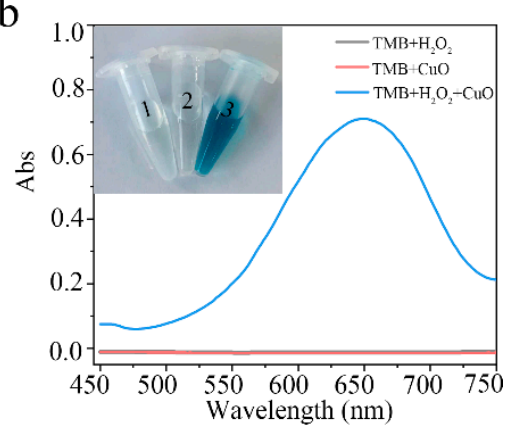

e

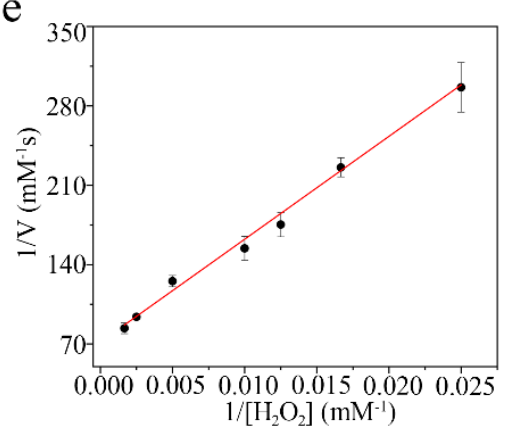

Figure 2. (a) Schematic detection of $\mathrm{H}_{2} \mathrm{O}_{2}$ using mesoporous $\mathrm{CuO}$ hollow sphere nanozymes. (b) UV-Vis absorption spectra of $\mathrm{TMB}+\mathrm{H}_{2} \mathrm{O}_{2}(1), \mathrm{TMB}+\mathrm{CuO}$ (2) and $\mathrm{TMB}+\mathrm{H}_{2} \mathrm{O}_{2}+\mathrm{CuO}$ (3). Insets correspond to optical photographs. (c) Time-dependent absorbance at $652 \mathrm{~nm}$ with different concentrations of $\mathrm{H}_{2} \mathrm{O}_{2}$ : (a) 10, (b) 20, (c) 40, (d) 80, (e) 100, (f) 300, (g) 400 and (h) 600 mM. (d) Steady-state kinetic analysis and (e) double-reciprocal plotting for Cu-TA-350 with $\mathrm{H}_{2} \mathrm{O}_{2}$ as the substrate.

To further evaluate the peroxidase-like activity of $\mathrm{Cu}-\mathrm{TA}-350$, the steady-state catalytic kinetics were investigated at room temperature in a reaction system containing $\mathrm{Cu}-\mathrm{TA}-350$, TMB and $\mathrm{H}_{2} \mathrm{O}_{2}$ of varied concentrations (10-600 mM) in PBS buffer solution. The timedependent absorbance variation of the reaction solution was monitored in time scan mode at $652 \mathrm{~nm}$ using a UV-Vis spectrophotometer (Figure 2c). Typical Michaelis-Menten curves were also obtained by altering the concentration of $\mathrm{H}_{2} \mathrm{O}_{2}$ (Figure 2d). Then, $K_{m}$ and $V_{\max }$ of the catalytic reaction by $\mathrm{Cu}-\mathrm{TA}-350$ were determined by the Lineweaver-Burk plot (Figure 2e). $K_{m}$ and $V_{\max }$ values were calculated to be $12.67 \times 10^{-1} \mathrm{M}$ and $1.396 \times 10^{-5} \mathrm{M} \mathrm{s}^{-1}$, respectively, which was comparable to other excellent nanozymes (Table S1).

\section{3. $\mathrm{H}_{2} \mathrm{O}_{2}$ Detection}

TMB can be oxidized in the presence of $\mathrm{H}_{2} \mathrm{O}_{2}$ by the catalysis of $\mathrm{Cu}-\mathrm{TA}-350$. The oxidized TMB solution showed a blue color with strong absorption at $652 \mathrm{~nm}$. The absorption was depended on the concentration of $\mathrm{H}_{2} \mathrm{O}_{2}$. It can be used as a colorimetric assay for $\mathrm{H}_{2} \mathrm{O}_{2}$ by monitoring the production of colored products at $652 \mathrm{~nm}$ by spectroscopy or visual observation. When the concentration of $\mathrm{H}_{2} \mathrm{O}_{2}$ varied from 10 to $600 \mu \mathrm{M}$, the intensity of absorbance peak gradually increased (Figure $3 a, b)$. The optical photos of different concentrations of $\mathrm{H}_{2} \mathrm{O}_{2}(0-600 \mu \mathrm{M})$ reaction samples are shown in Figure S4. The linear relationship was in the range of $10-200 \mu \mathrm{M}$. The detection limit of $\mathrm{H}_{2} \mathrm{O}_{2}$, was $2.1 \mu \mathrm{M}$ (Figure 3c). In addition, to test selectivity, control experiments were conducted using common metal ions and amino acids. The $\mathrm{H}_{2} \mathrm{O}_{2}$ group showed a high absorbance at $652 \mathrm{~nm}$, and the color of TMB significantly changed (Figure 3d). These results indicated 
that $\mathrm{Cu}-\mathrm{TA}-350$ was expected to realize the detection of $\mathrm{H}_{2} \mathrm{O}_{2}$ in complex samples. According to the fact that $\mathrm{H}_{2} \mathrm{O}_{2}$ is used as a preservative agent in milk [55], the practicability of mesoporous $\mathrm{Cu}$-TA-350 in the detection of $\mathrm{H}_{2} \mathrm{O}_{2}$ in commercial milk was performed. As shown in Table $\mathrm{S} 2$, there was no $\mathrm{H}_{2} \mathrm{O}_{2}$ detected as expected. When adding different concentrations of $\mathrm{H}_{2} \mathrm{O}_{2}$ to the samples, the recovery was in the range of 99.8-105.5\%. All relative standard deviation (RSD) was below $3.5 \%$, indicating that $\mathrm{Cu}-\mathrm{TA}-350$ was reliable and applicable to detect the $\mathrm{H}_{2} \mathrm{O}_{2}$ in complicated samples.
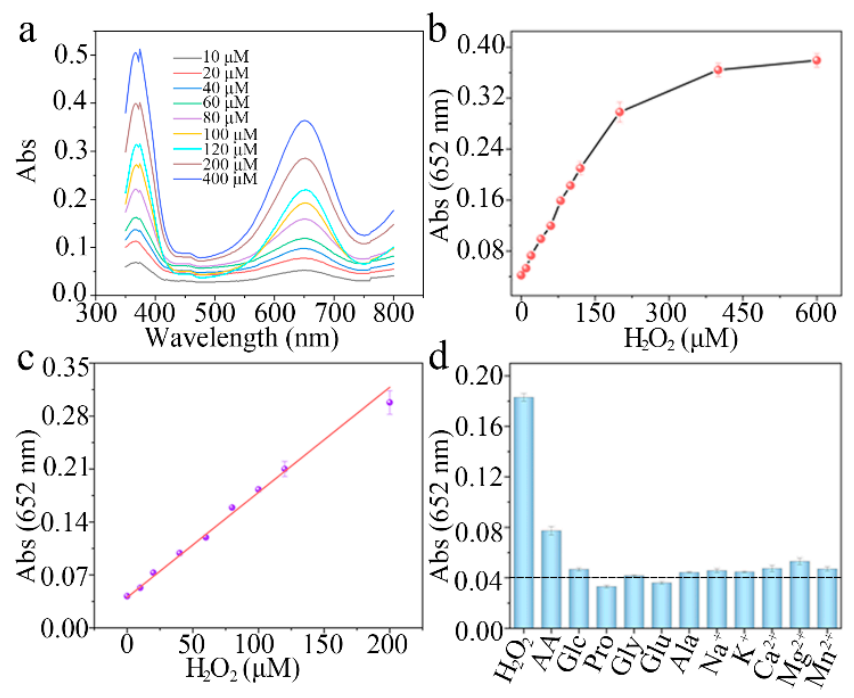

Figure 3. (a) UV-Vis absorbance spectra of Cu-TA-350 at different concentrations of $\mathrm{H}_{2} \mathrm{O}_{2}$ $(10-400 \mu \mathrm{M})$. (b) Absorption spectra of Cu-TA-350 at different concentrations of $\mathrm{H}_{2} \mathrm{O}_{2}$. (c) The linear absorbance response in the $\mathrm{H}_{2} \mathrm{O}_{2}$ concentration ranged from 10 to $200 \mu \mathrm{M}$. (d) UV-Vis absorbance spectra of $\mathrm{Cu}$-TA-350 solution in the presence of different $\mathrm{H}_{2} \mathrm{O}_{2}, \mathrm{AA}, \mathrm{GSH}$ and amino acids (100 $\mu \mathrm{M}$ each). The concentrations of metal ions and glucose were $1 \mathrm{mM}$. The black line represents the value of the blank group.

\subsection{Paper-Based Sensor}

The mesoporous $\mathrm{CuO}$ hollow spheres were then used to fabricate the paper-based chemical sensor for detection of $\mathrm{H}_{2} \mathrm{O}_{2}$ (Figure 4). The paper-based sensor was fabricated by deposition of $\mathrm{CuO}$ and $\mathrm{TMB}$ on the filter paper. Mesoporous $\mathrm{CuO}$ hollow spheres were well loaded onto the filter paper (Figure S5). The loading amount was around $0.17 \mathrm{mg} / \mathrm{cm}^{2}$ (Figure S6). When $5 \mu \mathrm{L}$ of different concentrations of $\mathrm{H}_{2} \mathrm{O}_{2}$ was dropped on the paper sensor, the paper sensor showed a blue color. The color could be read by the camera of a smartphone (e.g., an iPhone 12). Finally, the complementary blue color was used for quantitative analysis of the concentration of $\mathrm{H}_{2} \mathrm{O}_{2}$. As a result, $\mathrm{H}_{2} \mathrm{O}_{2}$ can be quantified by the fitting relationship between the RGB ratio and $\mathrm{H}_{2} \mathrm{O}_{2}$ concentration. Figure 4 shows the linear relationship of the intensity of $\mathrm{RGB}$ to $\mathrm{H}_{2} \mathrm{O}_{2}$ concentration in the range of 10-150 $\mu \mathrm{M}$ and the $G /(R+G+B)$ value of $0.344-0.366$. The lowest detectable concentration of the paper-based visual sensor is approximately $2 \mu \mathrm{M}$. The concentration of hydrogen peroxide in the environment can reach $2.23 \mu \mathrm{M}$ [56]. The concentration of hydrogen peroxide in the cells of the human body is from 50 to $100 \mu \mathrm{M}$ [57]. The likely normal range of $\mathrm{H}_{2} \mathrm{O}_{2}$ in plasma is $1-5 \mu \mathrm{M}$. It may go up to as high at $50 \mu \mathrm{M}$ in cases of inflammatory disease [58]. Compared with previously reported $\mathrm{H}_{2} \mathrm{O}_{2}$ sensors (Table S3), the proposed paper-based sensor has a desirable linear range and limit of detection. 


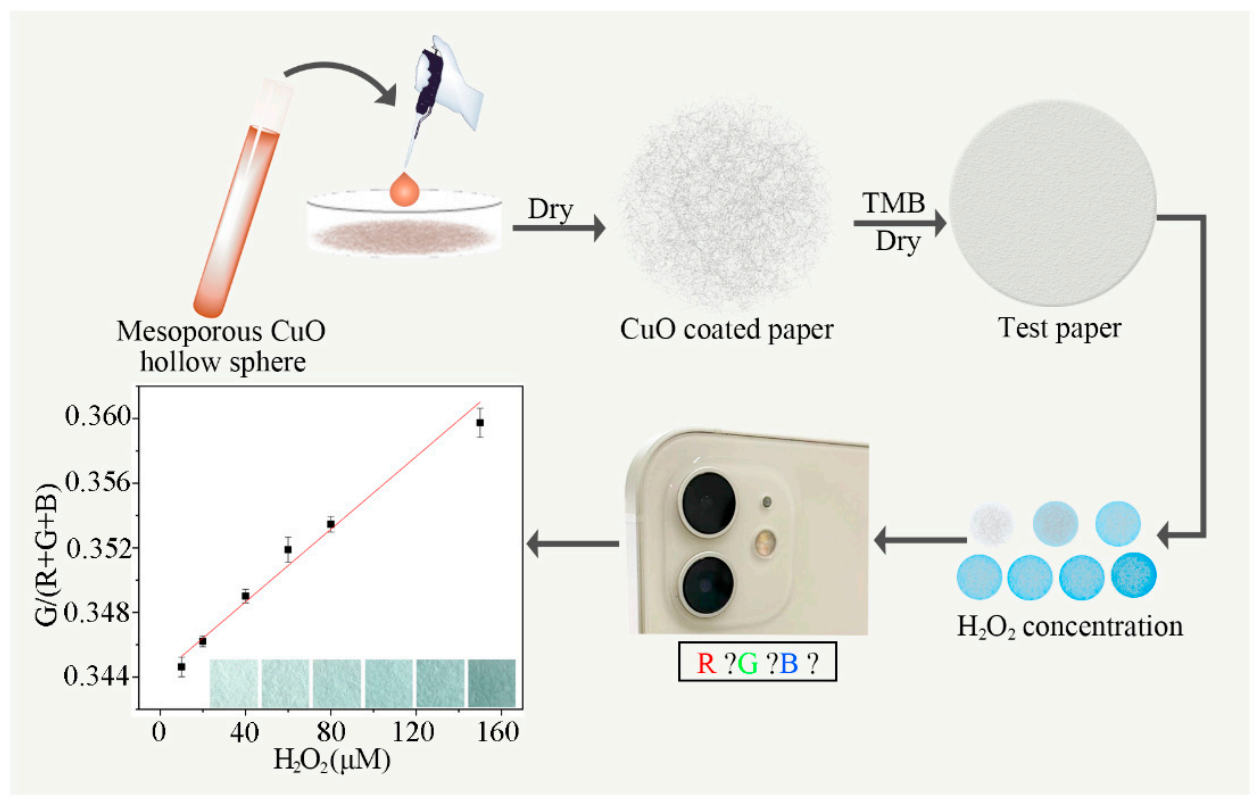

Figure 4. Schematic illustration of the fabrication of mesoporous metal oxide hollow sphere nanozyme-based paper as a colorimetric sensor for $\mathrm{H}_{2} \mathrm{O}_{2}$ detection. A smartphone was used to analyze the results.

To the best of our knowledge, the detection of $\mathrm{H}_{2} \mathrm{O}_{2}$ using a mesoporous $\mathrm{CuO}$ hollow sphere-based paper sensor has not yet been explored. Further study was also performed on the selectivity of the paper-based sensor for $\mathrm{H}_{2} \mathrm{O}_{2}$ detection. The paper-based sensor showed no obvious response in absence of $\mathrm{H}_{2} \mathrm{O}_{2}$ (Figure 5). This result demonstrated that the paper-based sensor had good selectivity of $\mathrm{H}_{2} \mathrm{O}_{2}$ (Figure 5a). Nine repeated experiments showed that the paper-based sensor had good repeatability (Figure $5 b$ ). Furthermore, the paper-based sensors can be stored for at least one month at $25^{\circ} \mathrm{C}$ in a sealed bag (Figure 5c). These results demonstrated that the paper-based sensor showed excellent performance and could potentially be applied in practical applications.
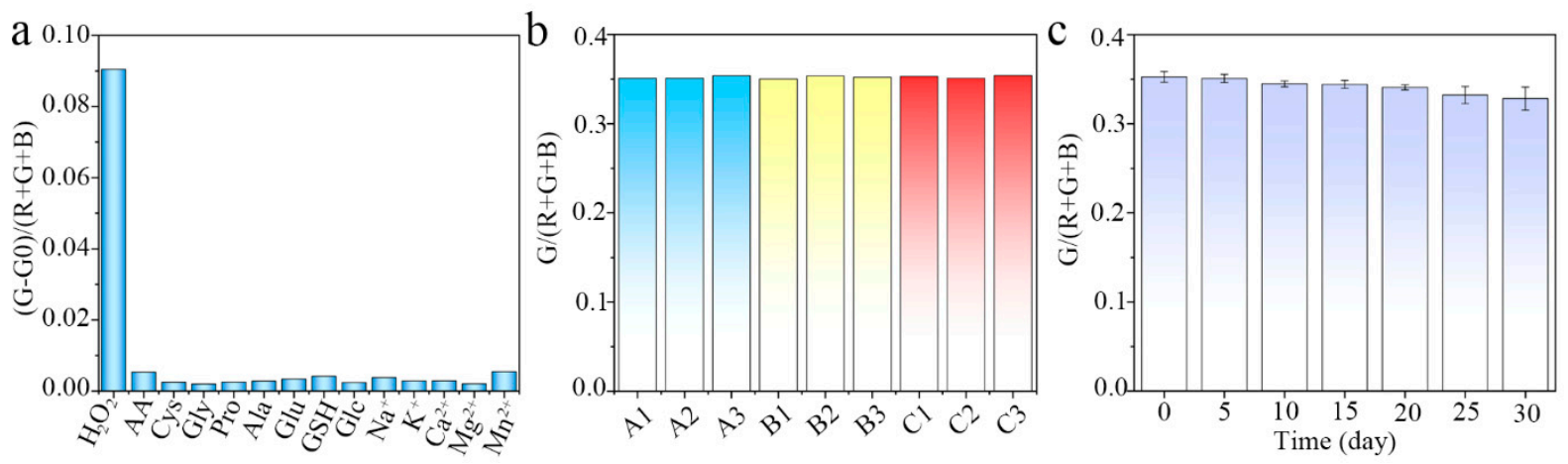

Figure 5. (a) Comparison of the sensing performance for various species $\mathrm{H}_{2} \mathrm{O}_{2}$, AA, Cys, Gly, Pro, Ala, Glu, GSH, Glc, $\mathrm{Na}^{+}, \mathrm{K}^{+}, \mathrm{Ca}^{2+}, \mathrm{Mg}^{2+}$ and $\mathrm{Mn}^{2+}$ using a paper-based sensor. The concentration of AA, GSH and amino acids was $100 \mu \mathrm{M}$. The concentration of metal ions and glucose was $1 \mathrm{mM}$. (b) Repeatability of the paper-based sensor for $\mathrm{H}_{2} \mathrm{O}_{2}$ detection by nine measurements from three batches (A, B and C). (c) Stability of the fabricated paper-based for $\mathrm{H}_{2} \mathrm{O}_{2}$ detection at room temperature.

\section{Conclusions}

In summary, a mesoporous $\mathrm{CuO}$ hollow sphere nanozyme is synthesized to fabricate a paper-based $\mathrm{H}_{2} \mathrm{O}_{2}$ sensor. The mesoporous $\mathrm{CuO}$ hollow sphere nanozyme is synthesized by direct thermal decomposition of metal-polyphenol coordination polymers. The obtained $\mathrm{CuO}$ nanozyme shows a high specific surface area, large pore size and hol- 
low structure. Such features can effectively enhance the peroxidase activity of the $\mathrm{CuO}$ nanozyme. The paper-based sensor can be used for colorimetric detection of $\mathrm{H}_{2} \mathrm{O}_{2}$ in the range of 2.4-150 $\mu \mathrm{M}$. Due to the hollow structure and mesoporous framework, such nanozymes could be used as a container to load other metal nanoparticles (e.g., Au) or natural enzymes, which would further expand the applications in the detection of other substances or biomedical therapy.

Supplementary Materials: The following are available online at https:/ /www.mdpi.com/article/10 .3390/bios11080258/s1, Figure S1: Characterization of Cu-TA-350, Figure S2: Catalytic activity of leaching solution and mesoporous $\mathrm{CuO}$ hollow sphere, Figure S3: Effect of different conditions on the activity of Cu-TA-350 nanozyme, Figure S4: Optical photographs of different concentrations of $\mathrm{H}_{2} \mathrm{O}_{2}$ reaction samples, Figure S5: SEM images of paper substrate without and with the deposition of Cu-TA-350, Figure S6: TG curves for filter paper and filter paper loaded with Cu-TA-350, Table S1: Comparison of the peroxidase-like activity of different nanomaterials of $\mathrm{H}_{2} \mathrm{O}_{2}$, Table S2: Detection of $\mathrm{H}_{2} \mathrm{O}_{2}$ in commercial milk samples, Table S3: Comparison of various nanomaterial-based sensors for $\mathrm{H}_{2} \mathrm{O}_{2}$ detection.

Author Contributions: Conceptualization, D.C. and Y.F.; methodology, D.C. and Y.F.; validation, D.C., J.Q. and Y.F.; formal analysis, D.C., J.Q. and Y.F.; investigation, D.C., J.Q. and Y.F.; resources, J.W.; data curation, D.C., J.Q. and Y.F.; writing—original draft preparation, D.C.; writing-review and editing, J.W.; funding acquisition, J.W. All authors have read and agreed to the published version of the manuscript.

Funding: This research was funded by the National Natural Science Foundation of China (No. 21701130) and Key Research and Development Program of Shaanxi (No. 2021GY-225).

Acknowledgments: We thank Zijun Ren at Instrument Analysis Center of Xi'an Jiaotong University for their assistance with SEM analysis.

Conflicts of Interest: The authors declare no conflict of interest.

\section{References}

1. Sies, H. Hydrogen peroxide as a central redox signaling molecule in physiological oxidative stress: Oxidative eustress. Redox Biol. 2017, 11, 613-619. [CrossRef] [PubMed]

2. Lou, Z.; Keli, H.; Han, K. Redox-Responsive Fluorescent Probes with Different Design Strategies. Acc. Chem. Res. 2015, 48, 1358-1368. [CrossRef]

3. Kalyanaraman, B.; Cheng, G.; Hardy, M.; Ouari, O.; Bennett, B.; Zielonka, J. Teaching the basics of reactive oxygen species and their relevance to cancer biology: Mitochondrial reactive oxygen species detection, redox signaling, and targeted therapies. Redox Biol. 2018, 15, 347-362. [CrossRef]

4. Winterbourn, C.C. Reconciling the chemistry and biology of reactive oxygen species. Nat. Chem. Biol. 2008, 4, 278-286. [CrossRef]

5. Brieger, K.; Schiavone, S.; Miller, J.; Krause, K.-H. Reactive oxygen species: From health to disease. Swiss Med. Wkly. 2012, 142, w13659. [CrossRef] [PubMed]

6. Lismont, C.; Revenco, I.; Fransen, M. Peroxisomal Hydrogen Peroxide Metabolism and Signaling in Health and Disease. Int. J. Mol. Sci. 2019, 20, 3673. [CrossRef] [PubMed]

7. Patel, V.; Kruse, P.; Selvaganapathy, P. Solid State Sensors for Hydrogen Peroxide Detection. Biosensors 2020, 11, 9. [CrossRef]

8. Dhara, K.; Mahapatra, D.R. Recent advances in electrochemical nonenzymatic hydrogen peroxide sensors based on nano-materials: A review. J. Mater. Sci. 2019, 54, 12319-12357. [CrossRef]

9. Lan, J.; Qi, D.; Song, J.; Liu, P.; Liu, Y.; Pan, Y.-X. Noble-metal-free cobalt hydroxide nanosheets for efficient electrocatalytic oxidation. Front. Chem. Sci. Eng. 2020, 14, 948-955. [CrossRef]

10. Song, M.; Wang, J.; Chen, B.; Wang, L. A Facile, Nonreactive Hydrogen Peroxide $\left(\mathrm{H}_{2} \mathrm{O}_{2}\right)$ Detection Method Enabled by Ion Chromatography with UV Detector. Anal. Chem. 2017, 89, 11537-11544. [CrossRef]

11. Ma, Y.S.; Cen, Y.; Sohail, M.; Xu, G.H.; Wei, F.D.; Shi, M.L.; Xu, X.M.; Song, Y.Y.; Ma, Y.J.; Hu, Q. A Ratiometric Fluorescence Universal Platform Based on N, Cu Co-doped Carbon Dots to Detect Metabolites Participating in $\mathrm{H}_{2} \mathrm{O}_{2}$-Generation Reactions. ACS Appl. Mater. Interfaces 2017, 9, 33011-33019. [CrossRef] [PubMed]

12. Wu, Z.; Liu, M.; Liu, Z.; Tian, Y. Real-Time Imaging and Simultaneous Quantification of Mitochondrial $\mathrm{H} 2 \mathrm{O} 2$ and ATP in Neurons with a Single Two-Photon Fluorescence-Lifetime-Based Probe. J. Am. Chem. Soc. 2020, 142, 7532-7541. [CrossRef] [PubMed]

13. Pan, F.; Zhang, Y.; Yuan, Z.; Lu, C. Sensitive and Selective Carmine Acid Detection Based on Chemiluminescence Quenching of Layer Doubled Hydroxide-Luminol- $\mathrm{H}_{2} \mathrm{O}_{2}$ System. ACS Omega 2018, 3, 18836-18842. [CrossRef] [PubMed]

14. Ye, S.; Hananya, N.; Green, O.; Chen, H.; Zhao, A.Q.; Shen, J.; Shabat, D.; Yang, D. A Highly Selective and Sensitive Chemiluminescent Probe for Real-Time Monitoring of Hydrogen Peroxide in Cells and Animals. Angew. Chem. Int. Ed. 2020, 59, 14326-14330. [CrossRef] 
15. Ding, Y.N.; Yang, B.C.; Liu, H.; Liu, Z.X.; Zhang, X.; Zheng, X.W.; Liu, Q.Y. FePt-Au ternary metallic nanoparticles with the enhanced peroxidase-like activity for ultrafast colorimetric detection of $\mathrm{H}_{2} \mathrm{O}_{2}$. Sens. Actuators $B$ Chem. 2018, 259, 775-783. [CrossRef]

16. Liu, H.; Ding, Y.; Yang, B.; Liu, Z.; Liu, Q.; Zhang, X. Colorimetric and ultrasensitive detection of $\mathrm{H}_{2} \mathrm{O}_{2}$ based on $\mathrm{Au} / \mathrm{Co} \mathrm{O} 4-\mathrm{CeOx}$ nanocomposites with enhanced peroxidase-like performance. Sens. Actuators B Chem. 2018, 271, 336-345. [CrossRef]

17. Cheng, Y.; Liang, L.; Ye, F.; Zhao, S. Ce-MOF with Intrinsic Haloperoxidase-Like Activity for Ratiometric Colorimetric De-tection of Hydrogen Peroxide. Biosensors 2021, 11, 204. [CrossRef] [PubMed]

18. Chinnadayyala, S.R.; Park, J.; Le, H.T.N.; Santhosh, M.; Kadam, A.; Cho, S. Recent advances in microfluidic paper-based electrochemiluminescence analytical devices for point-of-care testing applications. Biosens. Bioelectron. 2019, 126, 68-81. [CrossRef]

19. Parolo, C.; Merkoçi, A. Paper-based nanobiosensors for diagnostics. Chem. Soc. Rev. 2013, 42, 450-457. [CrossRef]

20. Giaretta, J.E.; Oveissi, F.; Dehghani, F.; Naficy, S. Paper-Based, Chemiresistive Sensor for Hydrogen Peroxide Detection. Adv. Mater. Technol. 2021, 6, 2001148. [CrossRef]

21. Kumar, S.; Pandey, C.M.; Hatamie, A.; Simchi, A.; Willander, M.; Malhotra, B.D. Nanomaterial-Modified Conducting Paper: Fabrication, Properties, and Emerging Biomedical Applications. Glob. Challenges 2019, 3, 1900041. [CrossRef] [PubMed]

22. Aydindogan, E.; Celik, E.G.; Timur, S. Paper-Based Analytical Methods for Smartphone Sensing with Functional Nanoparti-cles: Bridges from Smart Surfaces to Global Health. Anal. Chem. 2018, 90, 12325-12333. [CrossRef] [PubMed]

23. Xia, Y.Y.; Si, J.; Li, Z.Y. Fabrication techniques for microfluidic paper-based analytical devices and their applications for bi-ological testing: A review. Biosens. Bioelectron. 2016, 77, 774-789. [CrossRef] [PubMed]

24. Zhang, W.; Niu, X.; Li, X.; He, Y.; Song, H.; Peng, Y.; Pan, J.; Qiu, F.; Zhao, H.; Lan, M. A smartphone-integrated ready-to-use paper-based sensor with mesoporous carbon-dispersed Pd nanoparticles as a highly active peroxidase mimic for $\mathrm{H}_{2} \mathrm{O}_{2}$ detection. Sensors Actuators B: Chem. 2018, 265, 412-420. [CrossRef]

25. Gao, L.Z.; Zhuang, J.; Nie, L.; Zhang, J.B.; Zhang, Y.; Gu, N.; Wang, T.H.; Feng, J.; Yang, D.L.; Perrett, S.; et al. Intrinsic pe-roxidase-like activity of ferromagnetic nanoparticles. Nat. Nanotechnol. 2007, 2, 577-583. [CrossRef]

26. Montini, T.; Melchionna, M.; Monai, M.; Fornasiero, P. Fundamentals and Catalytic Applications of CeO ${ }_{2}$-Based Materials. Chem. Rev. 2016, 116, 5987-6041. [CrossRef]

27. Li, D.; Liu, B.; Huang, P.-J.J.; Zhang, Z.; Liu, J. Highly active fluorogenic oxidase-mimicking NiO nanozymes. Chem. Commun. 2018, 54, 12519-12522. [CrossRef]

28. Ding, B.; Zheng, P.; Ma, P.; Lin, J. Manganese Oxide Nanomaterials: Synthesis, Properties, and Theranostic Applications. Adv. Mater. 2020, 32, e1905823. [CrossRef]

29. Ghosh, S.; Roy, P.; Karmodak, N.; Jemmis, E.D.; Mugesh, G. Nanoisozymes: Crystal-Facet-Dependent Enzyme-Mimetic Ac-tivity of $\mathrm{V}_{2} \mathrm{O}_{5}$ Nanomaterials. Angew. Chem. Int. Ed. 2018, 57, 4510-4515. [CrossRef]

30. Hu, A.L.; Deng, H.H.; Zheng, X.Q.; Wu, Y.Y.; Lin, X.L.; Liu, A.L.; Xia, X.H.; Peng, H.P.; Chen, W.; Hong, G.L. Self-cascade re-action catalyzed by $\mathrm{CuO}$ nanoparticle-based dual-functional enzyme mimics. Biosens. Bioelectron. 2017, 97, 21-25. [CrossRef]

31. Rezvani, E.; Hatamie, A.; Berahman, M.; Simchi, M.; Angizi, S.; Rahmati, R.; Kennedy, J.; Simchi, A. Synthesis, First-Principle Simulation, and Application of Three-Dimensional Ceria Nanoparticles/Graphene Nanocomposite for Non-Enzymatic Hydrogen Peroxide Detection. J. Electrochem. Soc. 2019, 166, H3167-H3174. [CrossRef]

32. Fu, R.; Zhou, J.; Wang, Y.; Liu, Y.; Liu, H.; Yang, Q.; Zhao, Q.; Jiao, B.; He, Y. Oxidase-like Nanozyme-Mediated Altering of the Aspect Ratio of Gold Nanorods for Breaking through $\mathrm{H}_{2} \mathrm{O}_{2}$-Supported Multicolor Colorimetric Assay: Application in the Detection of Acetylcholinesterase Activity and Its Inhibitors. ACS Appl. Bio. Mater. 2021, 4, 3539-3546. [CrossRef]

33. Li, M.; Zhang, H.; Hou, Y.; Wang, X.; Xue, C.; Li, W.; Cai, K.; Zhao, Y.; Luo, Z. State-of-the-art iron-based nanozymes for biocatalytic tumor therapy. Nanoscale Horiz. 2019, 5, 202-217. [CrossRef]

34. Giri, S.; Sarkar, A. Electrochemical Study of Bulk and Monolayer Copper in Alkaline Solution. J. Electrochem. Soc. 2016, 163, H252-H259. [CrossRef]

35. Khan, R.; Ahmad, R.; Rai, P.; Jang, L.W.; Yun, J.H.; Yu, Y.T.; Hahn, Y.B.; Lee, I.H. Glucose-assisted synthesis of Cu2O shu-riken-like nanostructures and their application as nonenzymatic glucose biosensors. Sens. Actuator B Chem. 2014, 203, 471-476. [CrossRef]

36. Chawla, M.; Sharma, V.; Randhawa, J.K. Facile One Pot Synthesis of CuO Nanostructures and Their Effect on Nonenzymatic Glucose Biosensing. Electrocatalysis 2016, 8, 27-35. [CrossRef]

37. Rath, P.C.; Patra, J.; Saikia, D.; Mishra, M.; Tseng, C.-M.; Chang, J.-K.; Kao, H.-M. Comparative study on the morpholo-gydependent performance of various $\mathrm{CuO}$ nanostructures as anode materials for sodium-ion batteries. ACS Sustain. Chem. Eng. 2018, 6, 10876-10885. [CrossRef]

38. Verma, N.; Kumar, N. Synthesis and Biomedical Applications of Copper Oxide Nanoparticles: An Expanding Horizon. ACS Biomater. Sci. Eng. 2019, 5, 1170-1188. [CrossRef]

39. Wu, Y.-P.; Zhou, W.; Dong, W.-W.; Zhao, J.; Qiao, X.-Q.; Hou, D.-F.; Li, D.-S.; Zhang, Q.; Feng, P. Temperature-Controlled Synthesis of Porous CuO Particles with Different Morphologies for Highly Sensitive Detection of Triethylamine. Cryst. Growth Des. 2017, 17, 2158-2165. [CrossRef]

40. Zhu, J.; Nie, W.; Wang, Q.; Li, J.; Li, H.; Wen, W.; Bao, T.; Xiong, H.; Zhang, X.; Wang, S. In situ growth of copper oxide-graphite carbon nitride nanocomposites with peroxidase-mimicking activity for electrocatalytic and colorimetric detection of hydrogen peroxide. Carbon 2018, 129, 29-37. [CrossRef] 
41. Wang, L.; Hou, J.; Liu, S.; Carrier, A.J.; Guo, T.; Liang, Q.; Oakley, D.; Zhang, X. CuO nanoparticles as haloperoxidase-mimics: Chloride-accelerated heterogeneous Cu-Fenton chemistry for $\mathrm{H}_{2} \mathrm{O}_{2}$ and glucose sensing. Sens. Actuators B Chem. 2019, 287, 180-184. [CrossRef]

42. Liu, T.; Guo, Y.; Zhang, Z.; Miao, Z.; Zhang, X.; Su, Z. Fabrication of hollow CuO/PANI hybrid nanofibers for non-enzymatic electrochemical detection of $\mathrm{H}_{2} \mathrm{O}_{2}$ and glucose. Sens. Actuators B Chem. 2019, 286, 370-376. [CrossRef]

43. Qiu, P.; Ma, B.; Hung, C.-T.; Li, W.; Zhao, D. Spherical Mesoporous Materials from Single to Multilevel Architectures. Accounts Chem. Res. 2019, 52, 2928-2938. [CrossRef]

44. Wang, G.; Yang, S.; Cao, L.; Jin, P.; Zeng, X.; Zhang, X.; Wei, J. Engineering mesoporous semiconducting metal oxides from metal-organic frameworks for gas sensing. Coord. Chem. Rev. 2021, 445, 214086. [CrossRef]

45. Purwajanti, S.; Zhang, H.W.; Huang, X.D.; Song, H.; Yang, Y.N.; Zhang, J.; Niu, Y.T.; Meka, A.K.; Noonan, O.; Yu, C.Z. Mesoporous Magnesium Oxide Hollow Spheres as Superior Arsenite Adsorbent: Synthesis and Adsorption Behavior. ACS Appl. Mater. Interfaces 2016, 8, 25306. [CrossRef]

46. Wei, J.; Sun, Z.K.; Luo, W.; Li, Y.H.; Elzatahry, A.A.; Al-Enizi, A.M.; Deng, Y.H.; Zhao, D.Y. New Insight into the Synthesis of Large-Pore Ordered Mesoporous Materials. J. Am. Chem. Soc. 2017, 139, 1706. [CrossRef]

47. Pahalagedara, M.N.; Pahalagedara, L.R.; Kuo, C.-H.; Dharmarathna, S.; Suib, S.L. Ordered Mesoporous Mixed Metal Oxides: Remarkable Effect of Pore Size on Catalytic Activity. Langmuir 2014, 30, 8228-8237. [CrossRef] [PubMed]

48. Zhang, H.; Noonan, O.; Huang, X.; Yang, Y.; Xu, C.; Zhou, L.; Yu, C. Surfactant-Free Assembly of Mesoporous Carbon Hollow Spheres with Large Tunable Pore Sizes. ACS Nano 2016, 10, 4579-4586. [CrossRef]

49. Wang, G.; Qin, J.; Feng, Y.; Feng, B.; Yang, S.; Wang, Z.; Zhao, Y.; Wei, J. Sol-Gel Synthesis of Spherical Mesoporous High-Entropy Oxides. ACS Appl. Mater. Interfaces 2020, 12, 45155-45164. [CrossRef] [PubMed]

50. Wang, H.; Bremner, D.H.; Wu, K.; Gong, X.; Fan, Q.; Xie, X.; Zhang, H.; Wu, J.; Zhu, L.-M. Platelet membrane biomimetic bufalin-loaded hollow $\mathrm{MnO} 2$ nanoparticles for MRI-guided chemo-chemodynamic combined therapy of cancer. Chem. Eng. J. 2020, 382, 122848. [CrossRef]

51. Wei, J.; Wang, G.; Chen, F.; Bai, M.; Liang, Y.; Wang, H.T.; Zhao, D.Y.; Zhao, Y.X. Sol-Gel Synthesis of Metal-Phenolic Coor-dination Spheres and Their Derived Carbon Composites. Angew. Chem. Int. Ed. 2018, 57, 9838-9843. [CrossRef] [PubMed]

52. Qin, J.; Liang, G.H.; Feng, Y.Y.; Feng, B.X.; Wang, G.; Wu, N.; Zhao, Y.X.; Wei, J. Synthesis of Gadolini-um/Iron-Bimetal-Phenolic Coordination Polymer Nanoparticles for Theranostic Applications. Nanoscale 2020, 12, 6096. [CrossRef] [PubMed]

53. Wang, G.; Qin, J.; Zhou, X.R.; Deng, Y.H.; Wang, H.T.; Zhao, Y.X.; Wei, J. Self-Template Synthesis of Mesoporous Metal Ox-ide Spheres with Metal-Mediated Inner Architectures and Superior Sensing Performance. Adv. Funct. Mater. 2018, 28, 1806144. [CrossRef]

54. Han, L.; Zhang, H.; Chen, D.; Li, F. Protein-Directed Metal Oxide Nanoflakes with Tandem Enzyme-Like Characteristics: Colorimetric Glucose Sensing Based on One-Pot Enzyme-Free Cascade Catalysis. Adv. Funct. Mater. 2018, 28, 1800018. [CrossRef]

55. da Silva, R.A.B.; Montes, R.H.; Richter, E.M.; Munoz, R. Rapid and selective determination of hydrogen peroxide residues in milk by batch injection analysis with amperometric detection. Food Chem. 2012, 133, 200-204. [CrossRef]

56. Ye, C.; Liu, P.; Ma, Z.; Xue, C.; Zhang, C.; Zhang, Y.; Liu, J.; Liu, C.; Sun, X.; Mu, Y. High $\mathrm{H}_{2} \mathrm{O}_{2}$ Concentrations Observed during Haze Periods during the Winter in Beijing: Importance of $\mathrm{H}_{2} \mathrm{O}_{2}$ Oxidation in Sulfate Formation. Environ. Sci. Technol. Lett. 2018, 5, 757-763. [CrossRef]

57. Samuilov, V.D.; Bezryadnov, D.V.; Gusev, M.V.; Kitashov, A.; Fedorenko, T.A. Hydrogen peroxide inhibits the growth of cyanobacteria. Biochemistry 1999, 64, 47-53.

58. Forman, H.J.; Bernardo, A.; Davies, K.J.A. What is the concentration of hydrogen peroxide in blood and plasma? Arch. Biochem. Biophys. 2016, 603, 48-53. [CrossRef] 